\title{
SEALING PERFORMANCE OF GASKETED FLANGE JOINTS - A PARAMETRIC STUDY
}

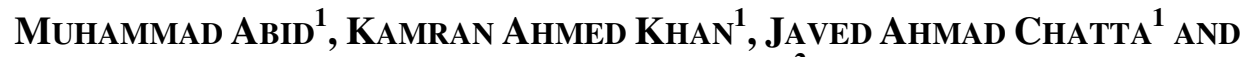 \\ HAFIZ ABDUL WAJID ${ }^{2}$ \\ ${ }^{I}$ Faculty of Mechanical Engineering, \\ GIK Institute of Engineering Sciences and Technology, Topi, Pakistan. \\ ${ }^{2}$ Department of Mathematics, COMSATS Institute of Information Technology, \\ Lahore, Pakistan. \\ abid@giki.edu.pk,chattha@giki.edu.pk,hawajid@ciitlahore.edu.pk
}

\begin{abstract}
This paper aims at finding the leak rate through ANSI class\#150 flange joints using compressed asbestos sheet gasket under combined structural and thermal transient loading conditions. The solution is obtained using two different leak rate models and two different bolt up values. The gasket compressive strain based model employs strains that are determined using finite element analysis. The other model is based on the porous media theory in which gasket is considered as a porous media. Leak rates determined using these leak rate models are compared for different tightness classes and discussed.
\end{abstract}

ABSTRAK: Kajian bertujuan mencari kadar bocor menerusi sambungan bebibir kelas ANSI\#150 menggunakan gasket kepingan asbestos termampat di bawah kondisi bebanan gabungan struktur dan terma fana. Solusinya diperolehi dengan menggunakan dua model kadar bocor yang berbeza dan dua nilai atas bolt yang berlainan. Model terikan berasaskan pemampat gasket menggunakan terikan yang ditentukan dengan analisis unsur terhingga. Model yang lainnya berasaskan teori bahantara berongga di mana gasket digunakan sebagai medium. Kadar bocor ditentukan dengan menggunakan model kadar bocor, yang kemudiannya dibandingkan pada kelas keketatan yang berbeza dan keputusannya dibincangkan.

KEYWORDS: bolted flange; gasket; leak rate; finite element analysis; tightness class compressive strains; porous media

\section{INTRODUCTION}

Conventional gasketed-flanged pipe joints are widely used in process industries for connecting pipes to pipes, and pipes to equipments. For bolted flange joints, two main concerns are joint strength and sealing capability. Present available design methods and codes address only the structural strength of the flange joint under internal pressure and do not consider the sealing capability of the joints under transient thermal loading. When gasketed-bolted connections are used in mechanical structures such as pipe flange connections, covers of pressure vessels in chemical plants, and the cylinder head in combustion engines, they are usually under thermal conditions. In the available published work, thermal behavior of the pipe flange joints is discussed under steady state loading with or without internal pressure [1-5] and under transient loading condition without internal pressure $[6,7]$. 
In this study, sealing behavior of different sizes of gasketed-bolted flanges joint under combined internal pressure and thermal transient loading is determined using finite element analysis and two available analytical leak rate models.

\section{FINITE ELEMENT MODELING}

ANSI 150\# flange sizes of $0.5,1,2,3,4,10,14,18$ and 24 inches are first analyzed numerically using ANSYS ${ }^{\circledR}$ software under combined internal pressure and transient properties. Neglecting the holes in the flange and the local effect of individual bolts around the flange, it is assumed that the system can be modeled as an axisymmetric structure. This may be thought of in the form of a continuous bolt ring with the bolt force applied at each bolt location. This provides a bolt force that is uniformly distributed along the circumference [8]. The resulting two dimensional flange joint models is shown in Fig. 1.

Structural element (PLANE 82) is used for the structural stress analysis of the flange joint. Thermal element (PLANE77) that is compatible with PLANE82 element is used to determine temperature distribution. Two-dimensional 'node-to-surface' CONTA172 contact elements, in combination with TARGE169 target elements are used to simulate contact distribution between flange face and gasket surface, the top of the flange, and the bottom of the bolt head. Friction is assumed negligible between surfaces, since the forces normal to the contact surfaces would be far greater than the shear force. Thermal and mechanical properties of flange and pipe, bolt, and gasket are taken from ref. [9].

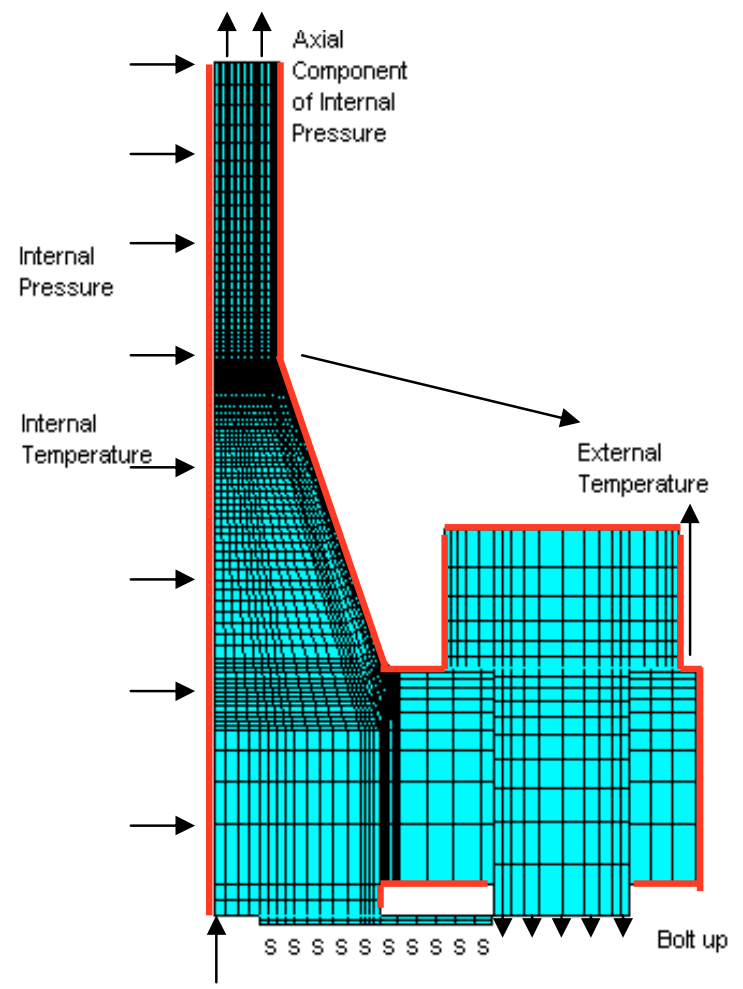

Fig. 1: FE model and applied boundary conditions.

\subsection{Thermal Boundary Conditions}

The initial thermal condition at time $\mathrm{t}=0$ seconds is a temperature of $\mathrm{T}=20^{\circ} \mathrm{C}$ (ambient). For time $t>0$, convective boundary conditions with internal temperature of 
$100^{\circ} \mathrm{C}$ with a convective heat transfer coefficient of $150 \mathrm{~W} / \mathrm{m}^{2} /{ }^{\circ} \mathrm{C}$ is applied at the pipe inner surface of the pipe, flange, and gasket. An ambient temperature of $20^{\circ} \mathrm{C}$ with a convective heat transfer coefficient of $20 \mathrm{~W} / \mathrm{m}^{2} /{ }^{\circ} \mathrm{C}$ is applied at the outer surface of pipe, flange, and gasket as shown in Fig. 1. The analysis is performed for 1500 seconds.

\subsection{Structural Boundary Conditions}

The flange is free to move in either the axial or radial direction, resulting in flange rotation. A symmetry condition is applied to the lower portion of the gasket. The bolt is constrained in the radial direction. The target torque depends on the flange size as specified by the process industry [10] and the gasket manufacturer [11] as shown in Table 1. The associated ASME code [12] does not specify a magnitude of preload for the bolts, referring only to a minimum seating stress that relates to the gasket style and composition. A certain displacement is applied at the bottom of the bolt to obtain a pre-stress condition. After pre-stress application, an internal pressure of $1.8 \mathrm{MPa}$ (18 bar) [10] is applied at the inner diameter of the flange and the gasket. Loading due to the head (end cap) is directly applied as nodal forces at the end of the pipe [8].

Table 1: Target torque values.

\begin{tabular}{cccccccc}
\hline Sr \# & $\begin{array}{c}\text { Flange } \\
\text { Size } \\
(\mathbf{I n})\end{array}$ & $\begin{array}{c}\text { Gasket } \\
\mathbf{I D} \\
(\mathbf{m m})\end{array}$ & $\begin{array}{c}\text { Gasket } \\
\text { OD } \\
(\mathbf{m m})\end{array}$ & $\begin{array}{c}\text { Target Torque } \\
\mathbf{( N - m )} \\
\text { Gasket } \\
\text { Manufacturer }\end{array}$ & $\begin{array}{c}\text { Target Bolt } \\
\text { Stress } \\
(\mathbf{M P a})\end{array}$ & $\begin{array}{c}\text { Target } \\
\text { Torque } \\
(\mathbf{N}-\mathbf{m}) \\
\text { industry }\end{array}$ & $\begin{array}{c}\text { Target Bolt } \\
\text { Stress } \\
(\mathbf{M P a})\end{array}$ \\
\hline $\mathbf{1}$ & 0.5 & 14.2 & 34.9 & 34.3 & 106.7 & 35 & 108.8 \\
$\mathbf{2}$ & 1 & 26.9 & 50.8 & 34.3 & 106.7 & 50 & 108.8 \\
$\mathbf{3}$ & 2 & 55.6 & 92.1 & 67.6 & 107.5 & 130 & 206.7 \\
$\mathbf{4}$ & 3 & 81.0 & 127.0 & 67.6 & 107.5 & 130 & 206.7 \\
$\mathbf{5}$ & 4 & 106.4 & 157.2 & 67.6 & 107.5 & 130 & 206.7 \\
$\mathbf{6}$ & 10 & 268.2 & 323.8 & 188.4 & 109.2 & 300 & 173.9 \\
$\mathbf{7}$ & 14 & 349.3 & 412.7 & 281.8 & 109.5 & 500 & 194.2 \\
$\mathbf{8}$ & 18 & 449.3 & 533.4 & 398.4 & 108.7 & 705 & 192.3 \\
$\mathbf{9}$ & 24 & 603.3 & 692.1 & 555.7 & 110.5 & 985 & 195.9 \\
\hline
\end{tabular}

\section{LEAKAGE ANALYSIS}

\subsection{Leak Rate Model Based on Gasketed Compressive Strains (LR-1)}

Leak from a flange joint is observed during operating conditions when there is insufficient contact stress on the gasket due to insufficient bolt load. In order to estimate the leak rate, a mathematical model based on the compressive strain of a gasket is proposed in ref. [13], as it provides a simplified test procedure eliminating the complex loading-unloading sequence on the gasket. The proposed gasket strain formulation also incorporates thermal loading on flange joint to estimate the leak rate.

Experimentally, leak rates through flange joints is observed to be directly proportional to the internal pressure and inversaly proportional to the gasket strains. The following equations 1 and 2 were derived from the experimental test data of compressed asbestos (CAS) gasket [13].

$$
L=\pi \lambda 2^{n}\left(\frac{n-1}{n}\right)^{n} h\left(b^{\frac{n-1}{n}}-a^{\frac{n-1}{n}}\right)^{-n} P^{n}
$$


where, $\lambda=c \cdot e^{\alpha \cdot \varepsilon}$ and $\beta$ is the shape factor which is defined as

$$
\beta=h\left(b^{\frac{n-1}{n}}-a^{\frac{n-1}{n}}\right)^{-n}
$$

$P=$ internal pressure (MPa); $\varepsilon=$ compressive gasket strain; $h=$ gasket height $(\mathrm{mm})$; $b=$ gasket outside diameter $(\mathrm{mm}) ; a=$ gasket inside diameter $(\mathrm{mm}) ; \beta=$ shape factor; $c, n$ and $\alpha$ are constants that are dependent on the gasket type.

For the non-asbestos compressed fiber sheet gasket, the values of $c, n$ and $\alpha$ are 0.474 , 1.35 and -57.8 respectively [13]. The main input in this model is the gasket strain ' $\varepsilon$ ' that is calculated from finite element analysis. This leak rate model is used for both gases and liquids. A detailed flow chart for the leak rate determination based on gasket compressive strain is shown in Fig. 2.

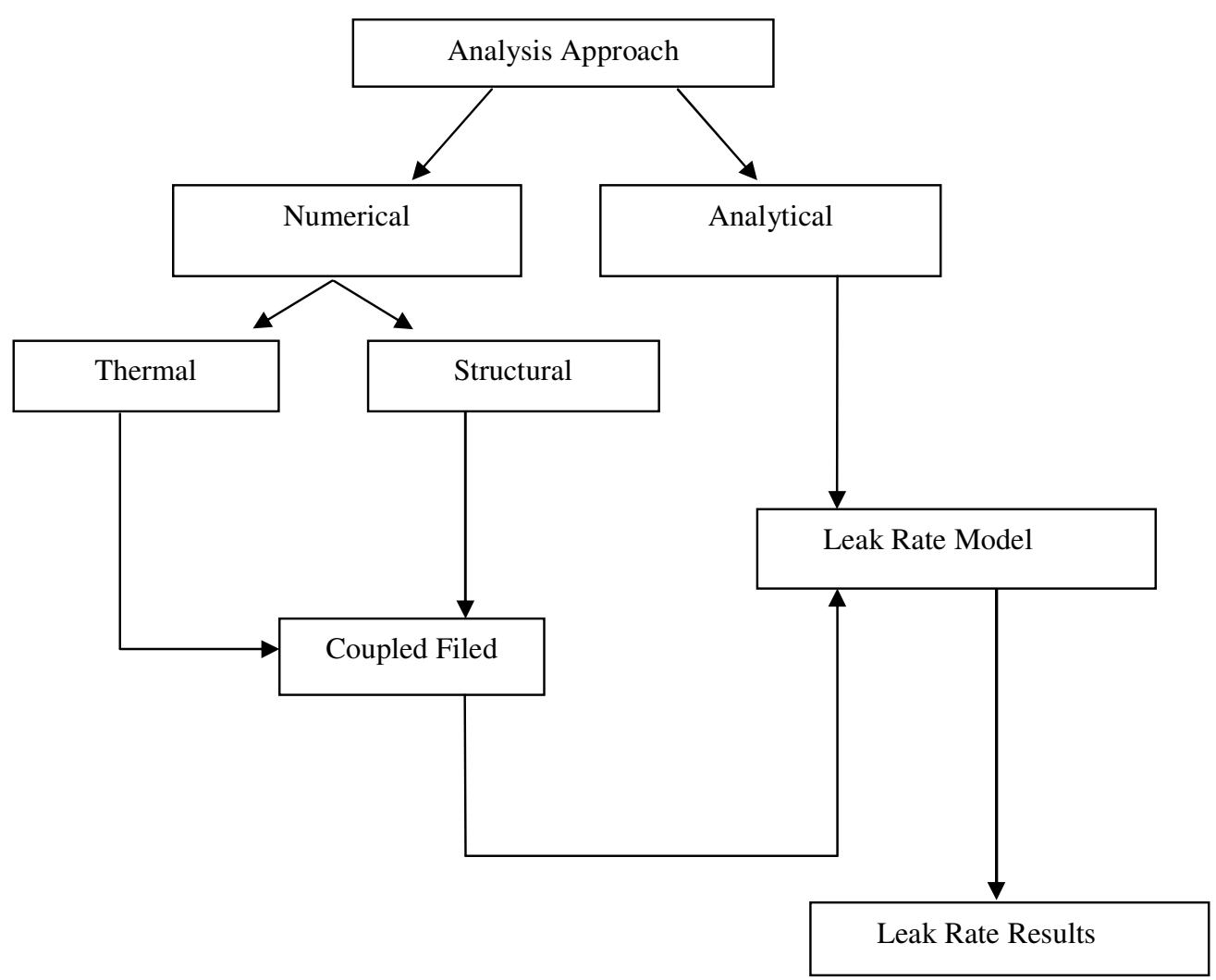

Fig. 2: Analysis flow chart using gasket compressive strains leak rate model (LR-1).

\subsection{Leak Rate Model Based on Porous Media Theory (LR-2)}

The leak prediction is also carried out using porous media theory by integrating Navier-Stokes equations with first order slip flow boundary conditions [14]. Equation 3 is applicable to a wide variety of gasket materials in which gasket permeability is the main factor to determine leak rate. 


$$
L_{r m}^{S F I}=\frac{\pi t k_{v} P_{o}^{2}}{\mu_{g} R_{g} T} \frac{P_{*}^{2}-1}{\ln \frac{r_{0}}{r_{i}}}
$$

Here, $L_{r m}=$ mass flow rate $(\mathrm{kg} / \mathrm{sec}) ; t=$ gasket thickness $(\mathrm{m}) ; k_{v}=$ gasket intrinsic permeability $\left(\mathrm{m}^{2}\right) ; P_{o}=$ ambient pressure $(\mathrm{MPa}) ; P_{*}=$ ration of the inlet over outlet pressures; $\mu_{g}=$ dynamic viscosity $\left(\mathrm{Pa} \mathrm{s}^{-1}\right) ; R_{g}=$ specific ideal gas constant $\left(\mathrm{J} \mathrm{kg}^{-1} \mathrm{~K}^{-1}\right) ; T=$ temperature $(\mathrm{K}) ; r_{o}, r_{i}=$ outer and inner radius of gasket.

Leak rate prediction for liquids by authors in ref. [14] validates the hypothesis of using gasket permeability from a reference gas test.

\section{RESULTS AND DISCUSSION}

\subsection{Leak Rate Model Based on Gasketed Compressive Strains (LR-1)}

Leak rate is determined from the flange joints using both gases and liquids. For liquids, crude oils of densities 915 and $973 \mathrm{~kg} / \mathrm{m}^{3}$ respectively are used. For gases, helium and nitrogen with densities of 0.1786 and $1.251 \mathrm{~kg} / \mathrm{m}^{3}$ respectively are used. KLINGERSIL ${ }^{\circledR}$ C4400 sheet gasket is used for crude oil, helium, and nitrogen. The leak rates were calculated by taking an initial contact area and effective contact area of the gasket (Fig. 3). Figures 4 to 7 show that leak rates for the effective contact area are less than the initial contact area of the flange joint. Figures 4 and 5, show variation in the leak rates for each size of the flange joint. The leak rate of nitrogen is observed to be more than that of helium for the same target torques as specified in ref. [10]. A maximum leak of 3.86 and $7.98 \mathrm{mg} / \mathrm{sec}$ is observed in the flange size of 4 inches for the target torques specified by the industry and gasket manufacturer respectively. The difference between the leak rates is due to the torques recommended which is higher in the industry specification case. This results in a higher generation of compressive gasket strain and lower leak rate. The leak rates of flange joints with sizes of 4,6 , and 8 inches are above the tightness class T3 [15] but the leak rates tend to decrease with the increase in flange size approaching the T3 regime. However, for the gasket manufacturer torque values, the leak rates of flange sizes from 2 to 24 inches are observed to be more than the T3 tightness class and lie in the T2.5 class for nitrogen gas. The leak rate of helium lies in the T3 class for both the target torque values. For crude oil, only the 0.5 and 1 inch flange sizes lie in the T2 class for both the recommended target torques, and the leak rate for the remaining flange sizes remains in the $\mathrm{T} 1$ class. This shows that the target torque values are recommended for the $\mathrm{T} 1$ class. To improve the leak rate, the target torque should be adjusted to meet the higher tightness class requirements.

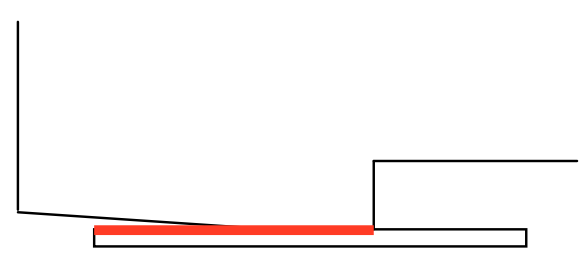

(a)

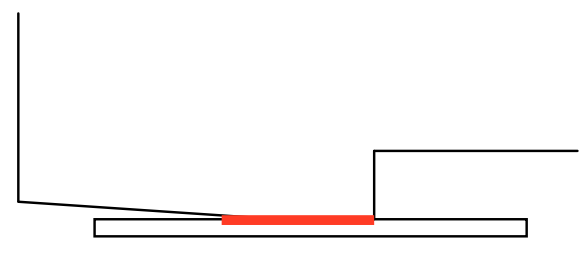

(b)

Fig. 3: (a) Initial contact area, (b) Effective contact area. 


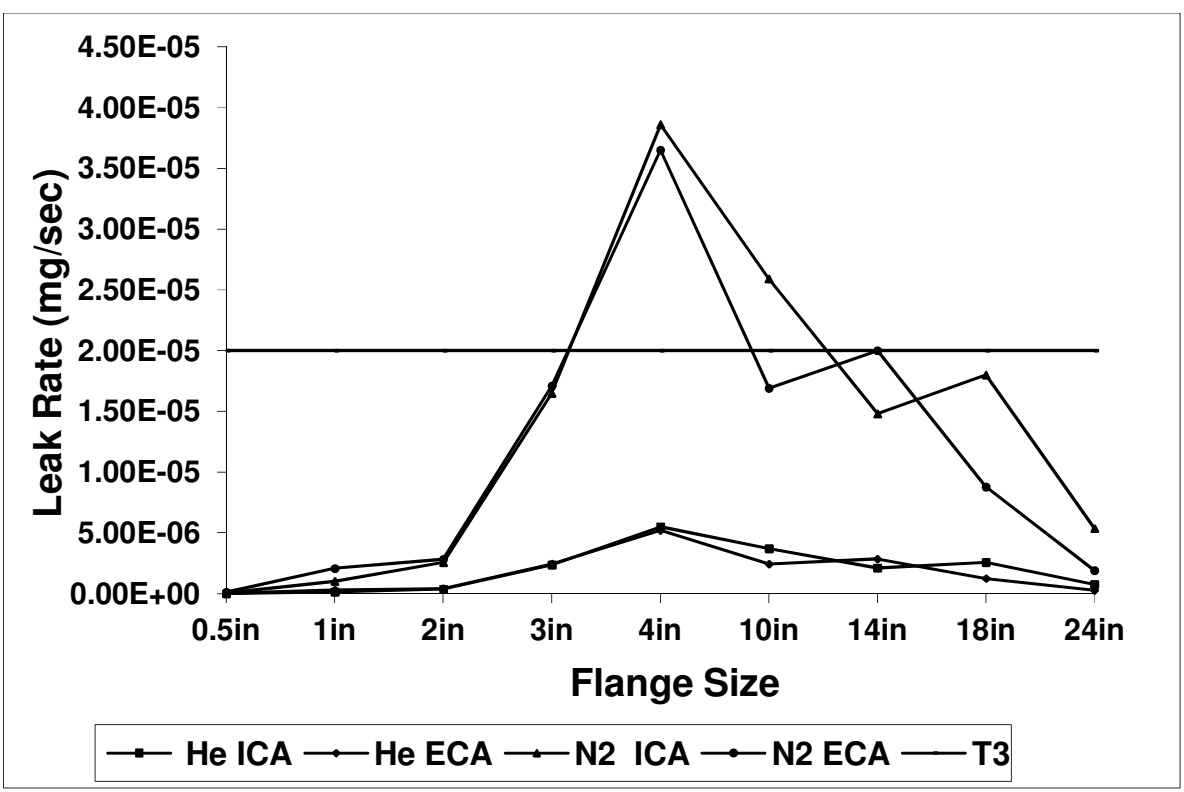

Fig. 4: Leak rate of gases using torques recommended by industry (ICA= Initial contact area, $\mathrm{ECA}=$ Effective contact area), $\mathrm{He}=$ Helium, $\mathrm{N} 2=$ Nitrogen.

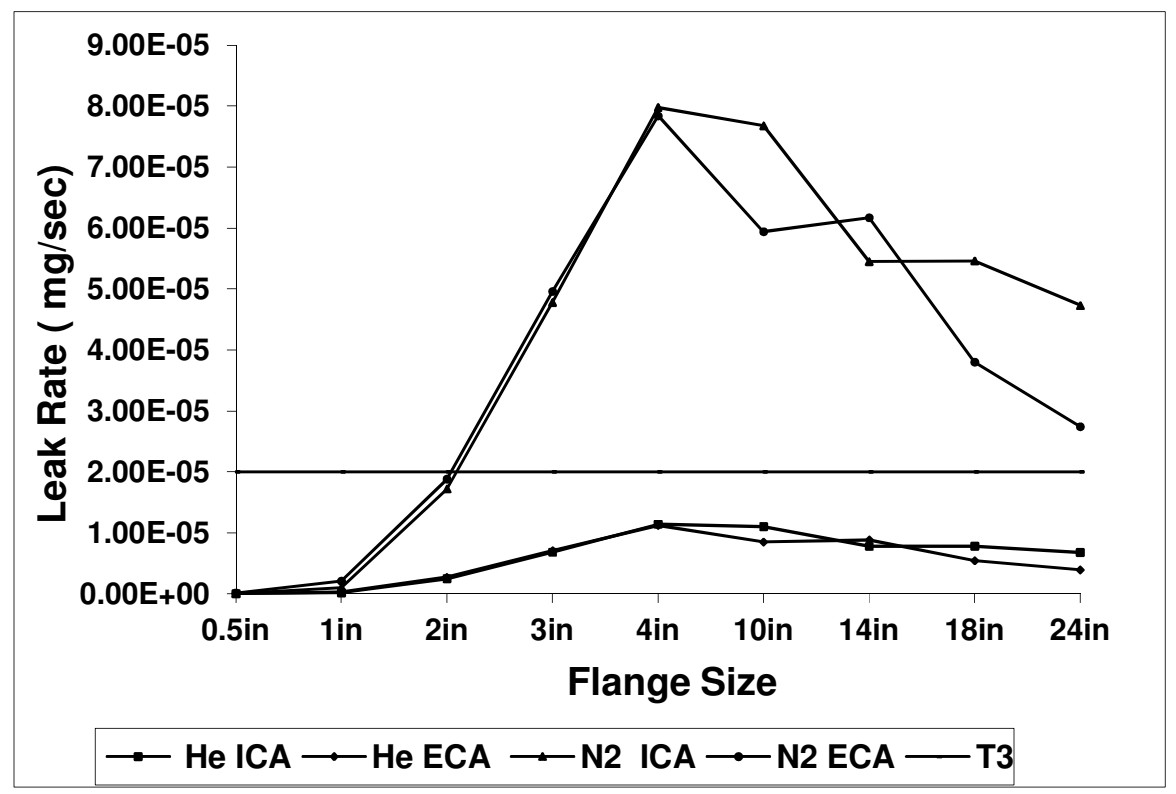

Fig. 5: Leak rate of gases using torques recommended by gasket manufacturer $(\mathrm{ICA}=$ Initial contact area, ECA= Effective contact area): He = Helium, N2 = Nitrogen. 


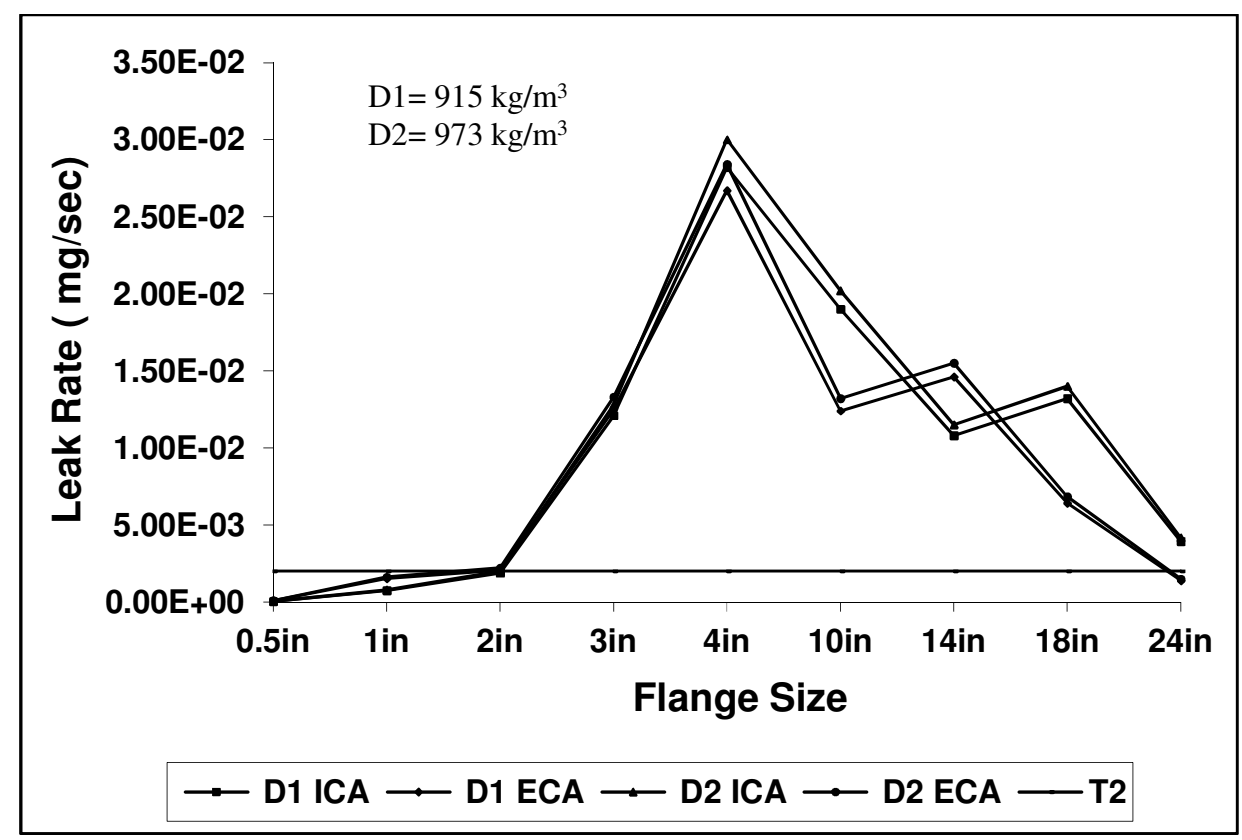

Fig. 6: Leak rate of crude oil using torques recommended by industry (ICA= Initial contact area, ECA= Effective contact area).

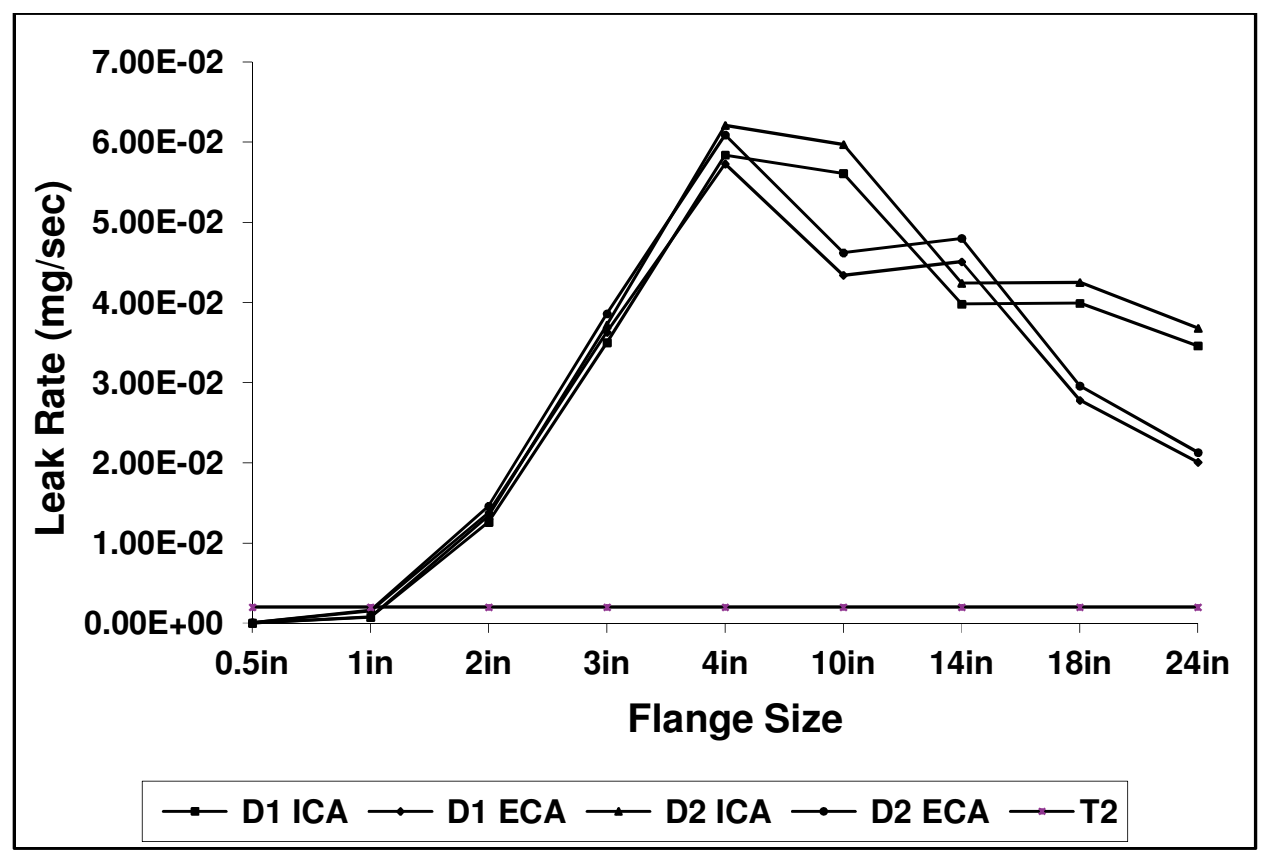

Fig. 7: Leak rate of crude oil using torques recommended by gasket manufacturer $(\mathrm{ICA}=$ Initial contact area, ECA= Effective contact area).

\subsection{Leak Rate Model Based on Porous Media Theory (LR-2)}

Using the porous media theory, high leak rates are observed for gases compared to the gasket compressive strains theory for the same gasket and boundary conditions (Fig. 8). For helium gas, all flange sizes qualified for the T2 tightness class except for the flange size of 4 inches which lies in the T1 class for target torques recommended by the gasket 
manufacturer. For nitrogen gas, only flange sizes of $0.5,1$ and 2 inches qualify for T2 class and remaining all flange sizes lie on tightness class $\mathrm{T} 1$ for both the target torques. It is obvious that the higher leak rate is obtained for the gasket manufacturer's recommended target torque as compared to the industry recommended torques. For the industry recommended target torque, the maximum leak rate of $8.19 \mathrm{E}-01 \mathrm{mg} / \mathrm{sec}$ is observed. For the gasket manufacturer's recommended target torque, the leak rate is observed to be 2.78 $\mathrm{mg} / \mathrm{sec}$ for the flange size of 4 inches. It is concluded that this is due to the higher value of the industry recommended target torque compared to the gasket manufacturer recommended setting.

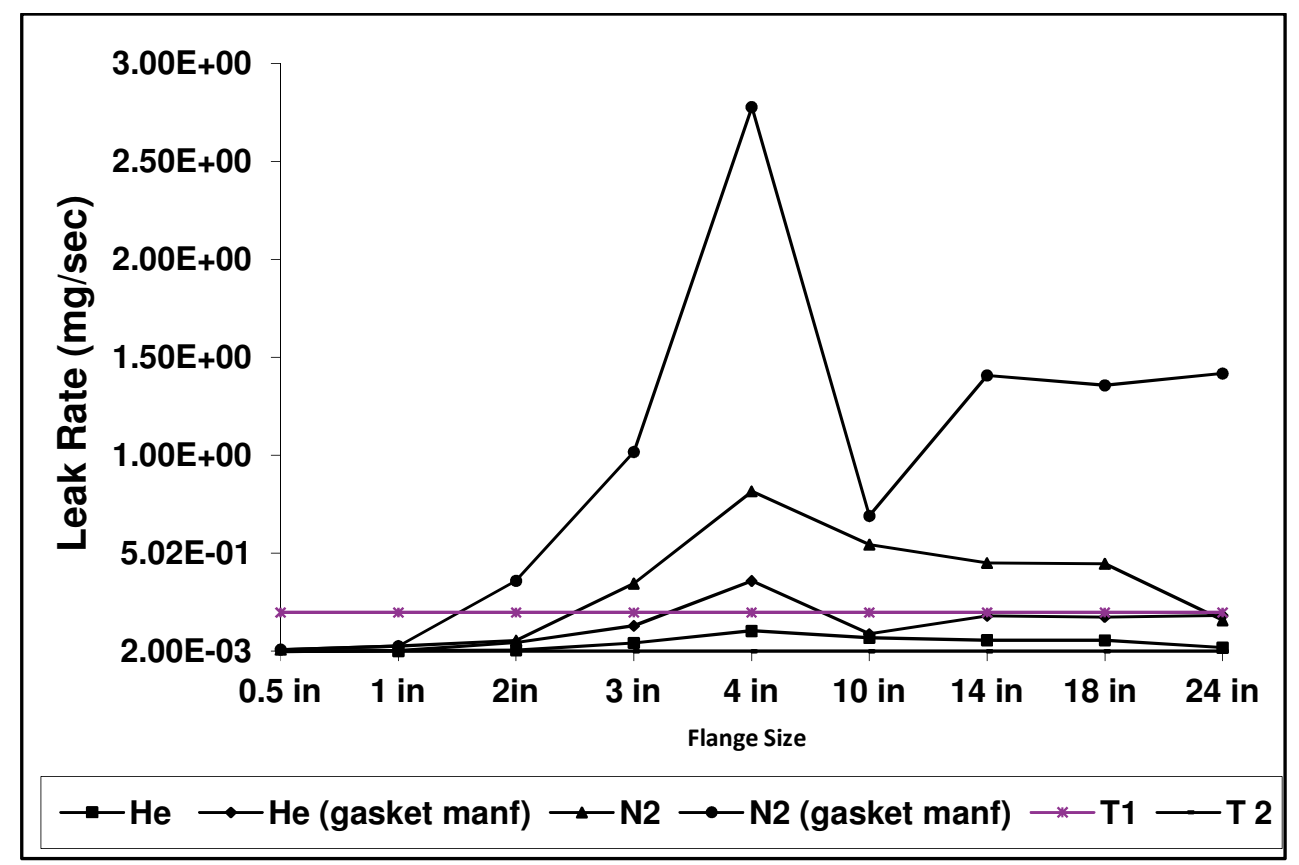

Fig. 8: Leak rate of gases using torques recommended by industry and gasket manufacturer. $\mathrm{He}=$ Helium, N2 = Nitrogen.

\section{CONCLUSIONS}

For ANSI Class\#150 flanges, different leak rates are calculated for different flange sizes. The maximum leak rate was found for the flange joint size of 4 inches using both leak rate models. The compressive strain based model predicts a higher leak rate compared to the porous media bases leak rate model. Compressive strain based model is applicable to liquids and gases but the gasket type is limited to a compressed asbestos sheet. The porous media based model that should be applicable to any type of gasket has been validated for gases only. For liquids, the model is yet to be checked and validated. For gas (nitrogen), the maximum leak rate is observed for the 4 inch flange size, which is $7.98 \mathrm{E}-8$ $\mathrm{kg} / \mathrm{sec}$ for LR-1 and $2.78 \mathrm{E}-06 \mathrm{~kg} / \mathrm{sec}$ for LR-2 using the gasket manufacturer's recommended target torque. For the case of crude oil, the leak rate was reduced by $50 \%$ when industry recommended target torque is applied. For the same target torque, flange sizes meet T2 tightness class requirement for liquids. However for the case of gases, flange sizes meet T3 tightness class requirement due to the difference in their densities. Industry recommended target torque is concluded to be better than the gasket manufacturer's target torques due to higher gasket stress and low leak rates. 


\section{ACKNOWLEDGEMENT}

The development of this work has been supported by the Higher Education Commission (HEC), Pakistan.

\section{REFERENCES}

[1] Abid M, Ullah B. (2007) Three-Dimensional Nonlinear Finite Element of gasketed flange joint under combined internal pressure and variable temperatures. J. of Engineering Mechanics 133(2):22-229.

[2] Kumano H, Sawa T, Hirose H. (1994) Mechanical behavior or bolted joint under steady heat conduction, ASME J. Pressure Vessel Technology 115(2):142-146.

[3] Bouzid AH, Nechache A, Brown W. (2002) The effect of steady state thermal loading on the deflections of a flanged joint with a cover plate. ASME Pressure Vessel and Piping Conference, Vancouver, British Columbia, Canada, August 5-9, 433:153-162.

[4] Brown W, Derenne M, Bouzid AH. (2000) Determination of the steady state operating temperature of pressure vessel flange components: Part-1- Analytic Methods. ASME Pressure Vessel and Piping Conference, Seattle, Washington, July 23-27, 405:5-104.

[5] Sawa T, Takagi Y, Tatsuoka T. (2005) Thermal stress analysis and evaluation of sealing performance in pipe flange connections with spiral wound gaskets under elevated temperature and internal pressure. ASME Pressure Vessel and Piping Conference. 105-113.

[6] Sawa T, Hirose T, Kumano H. (1993) Behavior of pipe flange connection in transient temperature field. ASME J. Pressure Vessel Technology 115:142-146.

[7] Brown W, Derenne M, Bouzid AH. (2002) Determination of Gasket stress levels during thermal transient. ASME Pressure Vessel and Piping Conference, Vancouver, British Columbia, Canada, August 5-9, 433:21-28.

[8] Nash DH, Spence J, Tooth AS, Abid M, Power DJ. (2000) A parametric study of metal-tometal full face taper-hub flanges, Int. J. Pres. Ves. \& Piping 77:791-797.

[9] Abid M, Chattha JA, Khan KA. (2007) Finite element analysis of a gasketed joint under combined internal pressure and thermal transient loading. ASME Pressure Vessel and Piping Conference, San Antonio, Texas, USA, July 22-26, p1-7.

[10] ES/090 Rev: 1. Design and Engineering Practices (DEPs), DEP 31.38.01.15.Gen (Piping Class Exploration and Production). 1998.

[11] http://www.klinger.co.uk

[12] Section VIII, ASME Boiler and Pressure Vessel Code, Design Considerations for bolted flange connections, Appendix-2, ASME, NY, USA. 1986.

[13] Kobayashi T, Nishida T, Suzuki M, Yamanaka Y. (2000) Leak Tightness Evaluation of Gaskets Based on Compressive Strain. ASME Pressure Vessel and Piping Conference, Seattle, Washington, July 23-27, (405):23-27.

[14] Jolly P, Marchand L. (2009) Leak Predictions for static gasket based on the porous media theory. J. Pr. Vessel Tech., Trans of the ASME. (131):021203:1-6.

[15] Bickford JH. (1998) Gaskets and Gasketed Joints. Marcel Dekker Inc. ISBN 0-8247-9877-5. 